\title{
Inequality: Underrepresentation of African American Males in U.S. Higher Education
}

\author{
Lorenda A. Naylor, Heather Wyatt-Nichol and Samuel L. Brown
}

University of Baltimore

\begin{abstract}
Although the percentage of Blacks earning college degrees has nearly doubled over the past 20 years, Blacks earn only $10 \%$ of college degrees, $12 \%$ of graduate degrees, and $7 \%$ of doctoral degrees (U.S. Census Bureau, 2013). Furthermore, Blacks are more likely to attend lower-quality institutions and less likely to graduate (Mettler, 2014). This translates into possibly fewer Black men completing degrees in public affairs education and seeking public service. If we are to secure a representative bureaucracy (Krislov, 2013; Naff, 2001) in which both public administrators and college faculty mirror the nation's demographics, then we must ensure that Black males have equal access to an affordable, quality college education resulting in degree completion. In this article, we examine disparities in higher education along three procedural areas: (a) access, (b) affordability, and (c) attainment. We provide substantive policy recommendations toward ensuring both access and degree attainment for all individuals regardless of race or income.
\end{abstract}

\section{KEYWORDS}

African American males, higher education, access, college attainment, inequity

Historically, education has been perceived as the great equalizer to establish a pathway to the middle class. However, the current higher education system perpetuates inequality. Tuition is too expensive, and most American families can no longer afford to send their children to college. From 1980 to 2011, college tuition increased by $244 \%$ (Mettler, 2014), reducing college opportunity for middle- and lowincome students. Current tuition rates also force students to take on enormous amounts of debt. The federal student loan debt has reached $\$ 1$ trillion, exceeding the U.S. credit card debt (Mettler, 2014; Naylor, Wooldridge, \& Lyles, 2014), and students owe another $\$ 200$ billion in private student loans (Blumenstyk,
2015). Although the United States spends $\$ 407$ billion annually on higher education (Carnevale, Strohl, \& Gulish, 2015), which is an exorbitant amount of money, the United States ranks 12 th in the world for degree attainment (Organisation for Economic Co-operation and Development, 2013).

Despite the inordinate amount of federal dollars spent on higher education, core groups of American society are underserved or left out of the college experience: low-income and minority students (Carnevale et al., 2015). Low-income and minority students are more likely to attend lower-tiered universities and more likely to graduate with larger student loan 
debt than high-income, nonminority students (Huelsman, 2015).

Mettler (2014) has identified degrees of inequality resulting in two separate systems: one for privileged White students, and one for low-income and minority students. According to Mettler (2014), "our system of higher education contributes, increasingly, to rising inequality, as it stratifies Americans by income group rather than providing them with ladders of opportunity" (p. 8). At the core of this problem is access, affordability, and attainment.

We propose that access, affordability, and attainment must be improved to increase opportunities for African American males. First, social equity is used as a theoretical framework to examine higher education-specifically a public affairs education based on democratic values of equality and diversity. Second, the construct of institutional racism is defined and described, underscoring its role in partially explaining educational outcomes for Black males. Next, relying on secondary data, the rules and procedures used by institutions of higher education to establish access, affordability, and attainment are deconstructed to emphasize the institution's responsibility in underwriting policies that promulgate the further disenfranchisement of low-income and minority students, and specifically Black males. Fourth, the role of diversity in NASPAA-accredited public affairs education is reviewed. Last, policy recommendations are offered to address disparities in higher education.

\section{SOCIAL EQUITY}

Influenced by the first Minnowbrook meeting and by scholars such as Dwight Waldo and $\mathrm{H}$. George Frederickson, the new public administration movement in the late 1960s asserted that traditional public administration focused on institutions rather than on the problems to be addressed by institutions (Wyatt-Nichol, Brown, \& Haynes, 2011). Generations later, the National Academy of Public Administration refers to social equity as the fourth pillar of public administration
(National Academy of Public Administration, 2005). Its Standing Panel on Social Equity in Governance defines social equity as follows:

The fair, just and equitable management of all institutions serving the public directly or by contract; the fair, just and equitable distribution of public services and implementation of public policy; and the commitment to promote fairness, justice, and equity in the formation of public policy (National Academy of Public Administration, n.d.).

In recent years, increasing income inequality has contributed to economic segregation among regions and neighborhoods and particularly within public school systems, as neighborhoods are a reflection of socioeconomic status and race (Pebley \& Sastry, 2004; Wyatt-Nichol et al., 2011). The negative impact of racial and socioeconomic segregation in public education contributes to disparities in higher education. In $2011,82 \%$ of high-income students went to college, compared to only $53 \%$ of low-income students (U.S. Department of Education, National Center for Education Statistics, 2012a). Moreover, students from upper income families are nine times more likely to graduate from college than students from lower income families (Mortenson, 2012).

Income is significant, because in the United States, family income level (Mortenson, 2012) and parent's level of education (Pew Charitable Trusts, 2011) are the most powerful predictors of a child's education level. Furthermore, race and class are intertwined, and Blacks are disproportionately overrepresented in poverty: Blacks comprise $13 \%$ of the U.S. population, but $24.1 \%$ of Blacks ages 18 to 64 live in poverty (U.S. Census Bureau, 2012c). This means that Black students (and other students from poor families) are less likely to graduate from college simply because of their incomenot ability, but income. This has negative long-term effects on earnings and economic mobility. Without a college degree, young ad- 
ults are less likely to be employed, and if they do find employment, they will earn less money. According to a report released by the College Board, an individual with a baccalaureate degree has median earnings $65 \%$ greater than an individual with a high school degree (Baum, Ma, \& Payea, 2013). In 2010, a four-year degree earned on average $\$ 40,000$ compared to a high school degree that earned $\$ 25,000$ for adults between the ages of 25 and 40 (Mettler, 2014). In 2013, bachelor's degree graduates earned an average of $\$ 48,500$ compared to $\$ 23,900$ for high school graduates (U.S. Department of Education, National Center for Education Statistics, 2015).

Low-income minorities are more likely to attend less-prestigious colleges and are less likely to graduate from college, and these results lower minorities' social and economic mobility. Procedural rules and policies set up in areas of college access and admissions, affordability, and attainment lower the chances of success for Blacks, other minorities, and students from low-income families. At the core of this issue is institutional racism.

\section{INSTITUTIONAL RACISM}

The concept of institutional racism is most often credited to Kwame Ture (Stokely Carmichael) and Charles Hamilton's 1967 work Black Power: The Politics of Liberation, in which they discuss examples of overt and covert forms of racism at the institution level (Ture \& Hamilton, 1992). When viewed through the lens of critical race theory (CRT), the achievement gap and school dropout rates for Black males can be explained as a disparate impact of institutional racism manifested in the form of tracking and similar ability-group practices within public educational systems.

For nearly 25 years, a group of interdisciplinary scholars have used CRT to help explain the puzzle of persistent racial inequalities. This framework emerged in response to the failure of traditional legal remedies to address the perpetuation of racial discrimination and the need for a language that can articulate the contemporary nature of institutional discrimination and that also comports with Ture and Hamilton's (1992) concept of institutional racism. A brief summary of CRT is offered by Solorzano and Yosso (2001, pp. 472-473) as five recurring themes:

1. the centrality of race and racism and their intersectionality with other forms of subordination;

2. the challenge to dominant ideology;

3. the commitment to social justice;

4. the centrality of experiential knowledge; and

5. the transdisciplinary perspective.

One aim of CRT is to develop a postmodern perspective to help frame the contemporary challenges of the perpetuation of racial discrimination.

When contemporary practices of educational and other related institutions are examined through the lens of CRT, the persistence of institutional racism can be identified. CRT scholars employ the concept of covert racism, from Ture and Hamilton (1992), to expose institutional behaviors that continue to perpetuate past racial discrimination in education. In the early application of CRT to develop a theory of education, Ladson-Billings and Tate (1995) outlined the linkage between racial domination and racial hegemony in education:

In schooling, the absolute right to exclude was demonstrated initially by denying blacks access to schooling altogether. Later it was demonstrated by the creation and maintenance of separate schools. More recently it has been demonstrated by white flight and the growing insistence on vouchers, public funding of private schools, and school choice. Within schools, absolute right to exclude is demonstrated by resegregation via tracking (Ladson-Billings \& Tate, 1995, p. 60). 
It is this institutionalized manner of perpetuation that Ture and Hamilton were trying to capture with their 1967 construct of institutional racism. The institution of slavery imposed restraints and punishments on a daily basis to prevent the education of Black slaves. This denial of education was sustained under Jim Crow with devices, circumstances, and institutions that did not require individual acts of racial discrimination. Under both institutional structures, there was an element of racial domination. As such, the intent of discrimination was clear, and it could be linked directly to specific unjust outcomes, thereby establishing a chain of causation.

Under the new forms of perpetuating discrimination, no rational government actor would engage in repeated, overtly discriminatory behaviors that have been deemed unconstitutional. Instead, an institutional body is more likely to develop rules and procedures that produce lasting impacts of a pervasive nature. When the complexity of these institutional acts is examined closely, the motive-centered doctrine of racial discrimination becomes nearly impossible to establish under a traditional liberal legal reasoning framework.

To understand the Black male academic achievement gap, CRT would encourage one to see the liberal constructs of formal equality and neutrality as tools that promote the interest of the majority and serve to maintain the status quo of inequality in education. CRT scholars challenge the dominant groups' claims of formal equality, neutrality, and ahistoricism (Dixson \& Rousseau, 2006; Matsuda, 1991; Solorzano \& Yosso, 2001). At its core, a CRT viewpoint exposes how the interests of the majority are served and maintained through contemporary institutional racism.

The early uses of ability grouping in public schools had a clear intent of racial discrimination, to separate Anglo American students from other marginalized groups in schools. The more contemporary uses of tracking and ability grouping in public education are considered under liberal rationalism to be facially neutral practices, meaning that they do not contain the objective proof of discriminatory intent needed to establish a prima facie violation of the equal protection clause of either the 5th or 14th Amendment as established in Washington $v$. Davis (1976).

From the perspective of CRT, tracking and ability grouping are yet additional forms of institutionalized racism because they effectively segregate students based on race, deny students an equal opportunity to a high-quality education, and leave an indelible mark on students' school experience and overall life chances (Braddock, 1990; Loveless, 1998; Viadero, 1998; Welner \& Oakes, 1996). Braddock and Dawkins (1993) report that minorities (with the exception of Asian Americans) are disproportion-

\section{TABLE 1.}

Education Level by Race, 25 Years and Older

\begin{tabular}{|l|c|c|c|c|}
\hline \multicolumn{1}{|c|}{ Education level } & All races & White & Black & Hispanic \\
\hline High school degree & $29.8 \%$ & $29.9 \%$ & $33.5 \%$ & $30.4 \%$ \\
\hline Baccalaureate degree & $20.1 \%$ & $22.5 \%$ & $13.7 \%$ & $10.7 \%$ \\
\hline Master's degree & $8.4 \%$ & $12.5 \%$ & $7.5 \%$ & $4.3 \%$ \\
\hline
\end{tabular}

Source. U.S. Census Bureau (2013). 
FIGURE 1.

Earnings and Unemployment Rates by Educational Attainment

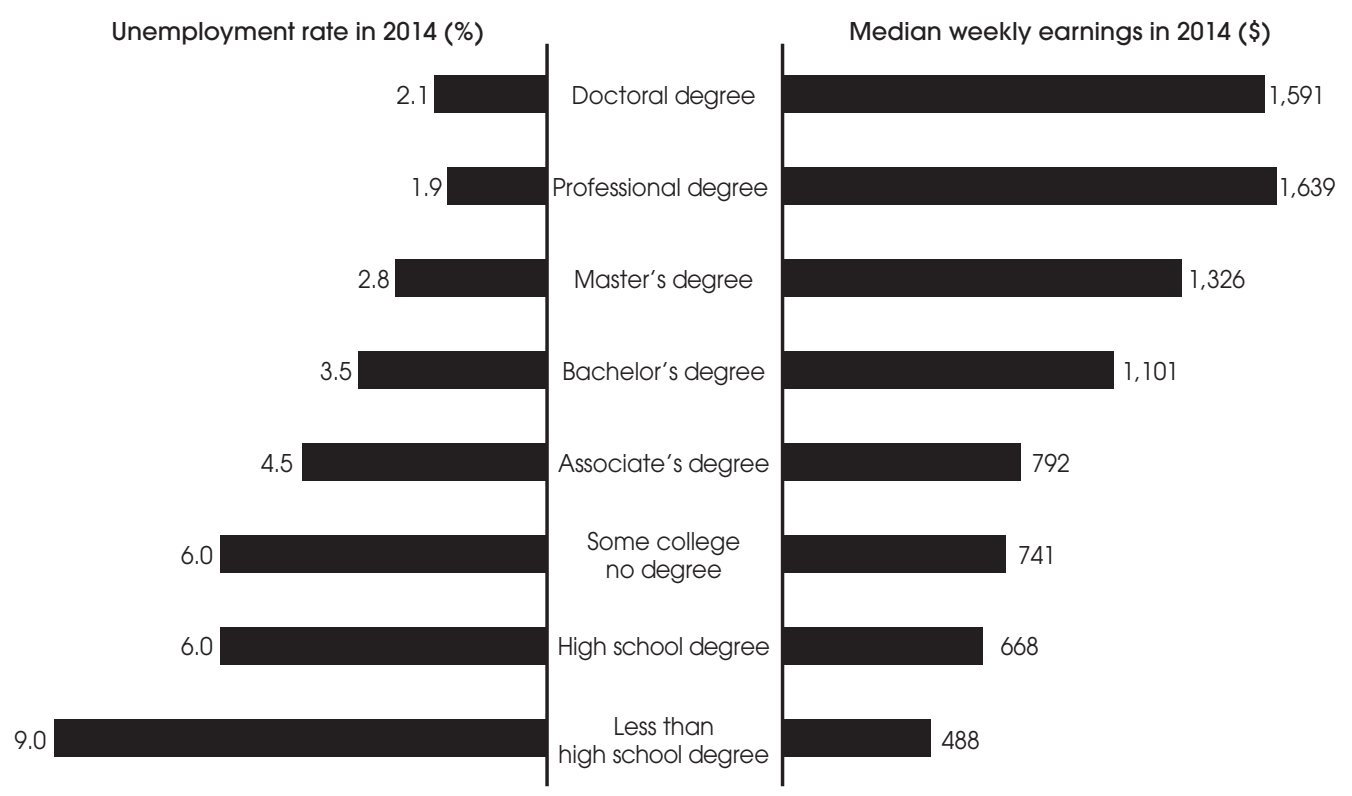

All workers: $5 \%$

All workers: $\$ 839$

Note. Data are for persons age 25 and over. Earnings are for full-time wages and salary workers.

Source. Current Population Survey, U.S. Bureau of Labor Statistics, U.S. Department of Labor.

ately enrolled in low tracks (vocational courses) and are correspondingly blocked from being enrolled in high tracks (AP courses) at high rates (pp. 326-28).

When the segregative effects of low-tracking minority students are combined with the response of the stereotype threat (Steele, 1997) which is the tendency of minority students to internalize negative stereotypes and disidentify with school achievement by developing an oppositional culture that links school achievement with the normativity of White experience (Ogbu, 2003) — the overall impacts are further magnified. The result is often that low-tracked students tend to perform at lower levels and to drop out of school at higher rates than highertracked students. This has a negative impact on Black male educational levels.
Following this discussion of the concept of institutional racism, the next section focuses on college attainment.

\section{COLLEGE DEGREE ATTAINMENT}

African American males are consistently overrepresented in poverty and underrepresented in the higher educational system. While the percentage of Blacks earning college degrees has nearly doubled over the past 20 years, Blacks still earn only $10 \%$ of college degrees, $12 \%$ of graduate degrees, and $7 \%$ of doctoral degrees (U.S. Census Bureau, 2013). According to the U.S. Census Bureau (2012a), Blacks comprise $13 \%$ of the U.S. civilian noninstitutionalized population, of which $46.6 \%$ are male and $53.4 \%$ are female, and Whites comprise 63\% of the noninstitutionalized population, of which $49 \%$ are male and $51 \%$ are female. 
As illustrated in Table 1, 33.5\% of the Black population 25 years and older hold a high school degree; $13.7 \%$ of the Black population 25 years and older hold a baccalaureate degree; and 7.5\% hold an advanced degree. Hispanics have similar educational levels (except for graduate degrees, in which Blacks are 3 percentage points higher), with $30.4 \%$ earning a high school degree, $10.7 \%$ earning a baccalaureate degree, and $4.3 \%$ with a master's degree. Although the percentages for educational attainment are similar between Blacks and Hispanics, there is a stark difference between Blacks and Whites. In comparison, $29.9 \%$ of the White population 25 years and older holds a high school degree, $22.5 \%$ a baccalaureate degree, and $12.5 \%$ an advanced degree (U.S. Census Bureau, 2012b). These percentages are significant and highlight disparities in the higher education system. These disparities also have long-term negative consequences on future earnings and social and economic mobility.

As illustrated in Figure 1, education is directly linked to income and provides a protective factor against unemployment. Based on the most current year of the Bureau of Labor Statistics data, 2014, individuals with less than a high school degree had an unemployment rate of $9 \%$. In comparison, the unemployment rate for those with a high school degree was $6 \%$; with a baccalaureate degree, $3.5 \%$; with a master's degree, $2.8 \%$; and with a doctoral degree, $2.1 \%$
(U.S. Department of Labor, Bureau of Labor Statistics, 2015). On average, the higher the level of degree, the less likely one is to be unemployed. In addition, there is a positive correlation between education and income.

On average, the higher the level of education, the higher the level of income, as well. Individuals with a high school diploma had a median weekly income of $\$ 668$, compared to $\$ 1,101$ for those with a baccalaureate degree-almost double the income of a high school graduates. Individuals with a master's degree fared even better, with a median weekly income of $\$ 1,326$, and those with a doctoral degree earned $\$ 1,591$ weekly (U.S. Department of Labor, Bureau of Labor Statistics, 2015). In sum, those with college degrees out-earn those without college degrees.

\section{Race and Gender}

The differences are more striking when educational level is further broken down by race and gender. As illustrated in Table 2, based on the most recent data, $12.9 \%$ of Black males have a college degree compared to $22.3 \%$ of White males. The differences are less stark when comparing Black females to White females: Approximately $14.3 \%$ of Black females age 25 and older earned a baccalaureate degree, compared to $21.7 \%$ of White females. In regards to advanced degrees, $6.3 \%$ of Black males hold an advanced degree compared to $13.2 \%$ of their White counterparts. Twice as many White males as Black males have an advanced degree.

\section{TABLE 2.}

Educational Level by Race and Gender, 25 Years and Older

\begin{tabular}{|l|c|c|c|c|}
\hline \multicolumn{1}{|c}{ Education level } & Black females & White females & Black males & White males \\
\hline Baccalaureate degree & $14.3 \%$ & $21.7 \%$ & $12.9 \%$ & $22.3 \%$ \\
\hline Graduate degree & $8.5 \%$ & $11.8 \%$ & $6.3 \%$ & $13.2 \%$ \\
\hline
\end{tabular}

Source. U.S. Census Bureau (2013).

Note. Data are for persons age 25 and older. Earnings are for full-time wage and salary workers. Data from the U.S. Department of Labor, Bureau of Labor Statistics, (n.d.), Current Population Survey. Retrieved from http://www.bls.gov/emp/ep_chart_001.htm 
Roughly $8.5 \%$ of Black females hold an advanced degree compared to $11.8 \%$ of White females (U.S. Census Bureau, 2013). It is noteworthy to point out that more graduate degrees are earned by Black females than Black males: $8.5 \%$ compared to $6.3 \%$. Although Black females have achieved reasonably good outcomes in the higher education system, Black males have not kept pace.

\section{Poverty and Income}

As illustrated in Tables 1 and 2 above, Blacks earn fewer baccalaureate and graduate degrees compared to their White peers. This disparity can be partially explained by income. Blacks are overrepresented in poverty-although Blacks comprise $13 \%$ of the U.S. population, $24.1 \%$ of U.S. Blacks aged 18 to 64 live in poverty (U.S. Census Bureau, 2012c). However, this does not explain why Black males earn fewer graduate degrees than their Black female counterparts.

In regards to earnings, $11.5 \%$ of the total U.S. population earn over $\$ 100,000$ per year, compared to $14 \%$ of Whites and $5.2 \%$ of Blacks (U.S. Census Bureau, 2012d). When including total money income (i.e., wages and salaries, net income from self-employment, and income other than earnings), the percentages are stark. Of the total U.S. population, $21 \%$ earn over $\$ 100,000$, with $24.1 \%$ of Whites compared to $10.4 \%$ of Blacks earning over $\$ 100,000$. This means that twice as many Whites than Blacks earn over $\$ 100,000$ (U.S. Census Bureau, 2012e).

As stated before, this is critical because income largely determines who graduates from college. "While half of all people from high-income families have a bachelor's degree by age 25 , just 1 in 10 people from low-income families do" (The White House, 2014, p. 3; see also Bailey \& Dynarski, 2011).

Meanwhile, attaining a college degree dramatically increases low-income students' chances of moving into higher income levels. In contrast, the chances of a child making it out of the bottom fifth of the income distribution quadruple with a college degree (Isaacs, Sawhill, $\&$ Haskins, 2008). Given that Blacks are overrepresented in the bottom income quartile, they are more likely to attend lower-quality institutions and less likely to graduate. These outcomes translate into fewer Black men completing college degrees and predictably fewer Black men seeking public affairs education and employment in public service.

In order to earn a college degree, however, a student must first get admitted to college. College attainment is influenced by the student's family income. Income determines who will graduate, and graduation is dependent upon which college a student attends. The next section addresses college access and admissions.

\section{COLLEGE ACCESS AND ADMISSIONS}

Rules and procedures regarding college access are important because they create lasting effects. College access is based on admissions procedures, which determine who gets accepted and into what type of institution. There are two types of admissions procedures: informal and formal. Informal processes are used to grant access to students who may not qualify based on merit but have strong political connections to the institution. This process tends to be invisible, but it is a part of the standard operating procedures of universities.

An example of the informal process may be seen in a recent investigation at the University of Texas at Austin. Over a period of six years, from 2009 to 2014, the university's president, Bill Powers, admitted approximately 75 students who lacked merit qualifications but had political ties. Powers argued that his decision was in the long-term interest of the university, however, his resignation letter was submitted with a final date of employment of June 2, 2015.

Another well-publicized case is from 2009 at the University of Illinois, which ran a separate admissions process for advantaged students (Rivard, 2015). Informal cases are difficult to track and monitor since there are no formal policies or procedures. 
The second type of admissions is formal. Formal procedures determine college access for the majority of student applicants. This includes both getting accepted and the type of college or university to which one is accepted. Getting accepted into college is based on the type of admissions policy adopted by the institution. In general, these are broken down into open admissions policies, which have minimum merit standards for acceptance, and selective admissions policies, which have high merit standards for acceptance.

Typically, community colleges and four-year public universities have open admissions policies, while private universities and researchbased public universities have selective admissions. In general, colleges have become more restrictive: "Colleges have grown more competitive, restricting access. While the number of applicants to four-year colleges and universities has doubled since the early 1970 s, available slots have changed little" (The White House, 2014, p. 3; see also Bound, Hershbein, \& Long, 2009). Roughly $85 \%$ of U.S. degree-granting four-year colleges accept $50 \%$ of all students who apply; these colleges account for approximately $80 \%$ of all undergraduate enrollments (Blumenstyk, 2015).

On the other end of the continuum, 2\% of colleges accept less than a quarter of student applicants (Blumenstyk, 2015). Upper income students are more likely to get accepted into the most selective universities, thus creating an elite system. Of all students admitted to the most prestigious universities, $70 \%$ are from families in the top income quartile (Carnevale \& Stroh, 2013). Among 146 selective colleges in the United States, only 3\% of freshmen represent families at the bottom quarter of the income distribution (Oldfield, Candler, \& Johnson, 2006). In addition, earnings are $45 \%$ higher for students who graduate from elite compared to non-elite institutions (Carnevale \& Stroh, 2013).

Carnevale and Stroh (2013) indicate that although Whites comprise $62 \%$ of college students, they represent $75 \%$ of the students enrolled at selective institutions-institutions which spend three to five times more on instruction than open admissions institutions do. In comparison, most Hispanics and African Americans end up at community colleges, openaccess universities, or for-profit institutions, which spend considerably less on instruction. Students at these institutions are less likely to graduate and have lower earnings after graduation, which indicates the existence of a separate system for low-income and minority students (Carnevale \& Stroh, 2013).

\section{For-Profit Institutions}

Racial disparities in student debt exists across institutions of higher education. Referencing the 2010 Survey of Consumer and Finances, Goldrick-Rab, Kelchen, and Houle (2014) indicate that $34 \%$ of Blacks carry student debt compared to $16 \%$ of Whites.

For-profit colleges, which have adopted open admissions practices, enroll over 4 million students annually (Association of Private Sector Colleges and Universities, 2013). The open admissions policies, along with targeted marketing strategies, may contribute to the overrepresentation of low-income and minority students. For instance, $86 \%$ of students attending for-profit colleges receive need-based financial aid; 63\% receive Pell Grants; 53\% have an annual income of less than $\$ 30,000$; $21 \%$ have annual incomes of less than $\$ 10,000$; $51 \%$ are first-generation college students; and approximately $46 \%$ are either African American or Hispanic (Association of Private Sector Colleges and Universities, 2012). In 2009, forprofit colleges received over $\$ 4$ billion in Pell Grants and \$20 billion in federal loans (U.S. Government Accountability Office, 2010).

On July 1, 2015, The U.S. Department of Education's Gainful Employment Regulation went into effect. The regulation requires that career training programs, including certificates in colleges and universities, report student debt-to-earnings data. Programs must demon- 
strate that the annual loan payments of an average graduate does not exceed $20 \%$ of his or her discretionary income. The new ruling is projected to impact a majority of training programs at for-profit institutions. However, the political controversy over the regulation continues. On June 23, 2015, the same day that Judge Bates of the U.S. District Court for the District of Columbia upheld the gainful employment regulation, a spending bill that blocked the regulation made it through the Senate Committee on Appropriations (American Council on Education, 2015).

\section{Undermatching}

When students who are high achieving and low income are more likely to enroll at less-selective universities, this is known as undermatching. Undermatching is another dimension of college access. Top students from low-income households don't attend the most selective colleges they are qualified to attend. Approximately half of low-income students undermatch (Smith, Pender, \& Howell, 2013). Instead they select institutions with lower requirements and less cost. Only $8 \%$ of high-achieving low-income students closely match universities by their ability (Hoxby \& Avery, 2013). As a result, they are less likely to graduate despite their abilities.

\section{COLLEGE AFFORDABILITY}

When students select a college, one of the primary factors is cost. The price of attending college has risen dramatically. From 1980 to 2011, college tuition increased by $244 \%$ (Mettler, 2014), which has reduced college opportunity for middle- and low-income students. Despite the fact that state university enrollment accounts for over $70 \%$ of all college students, these universities' budgets continue to decrease. After the 2008 financial crisis, there were severe budget cuts from state and local governments. From 2007 to 2012, public funding decreased by $23 \%$ on average per fulltime-equivalent student (Blumenstyk, 2015; State Higher Education Executive Officers, 2013). To offset reductions in state funding, public universities have increased their tuition fees, placing the burden on the middle-income and low-income students who can least afford it. In addition, Pell Grants have not kept up with tuition increases. In 1970, Pell Grants covered $80 \%$ of college costs; today they cover only $31 \%$, making it more difficult for lowincome and minority students to afford college (College Board, 2013).

For-profit institutions, which predominantly serve low-income and minority students, charge higher tuition than public universities do, and this increases the debt load for these students. For-profits charge $\$ 15,000$ in tuition per year for full-time students on average, compared to $\$ 8,655$ at public four-year universities and $\$ 3,131$ at community colleges (College Board, 2012). This is critical, because for-profit institutions, who mostly serve low-income and minority students, charge significantly higher tuition to the students who can least afford it. In fact, 93\% of their students who graduate with a baccalaureate degree have student loan debt in excess of $\$ 32,700$. These students of for-profit institutions have the highest student loan default rates, accounting for $50 \%$ of all three-year defaults (College Board, 2012) compared to $20 \%$ for public four-year, $12 \%$ for private nonprofit, and $19 \%$ for public two-year institutions.

\section{DIVERSITY AND NASPAA}

If we are to secure a representative bureaucracy (Krislov, 2013; Naff, 2001), one in which public administrators and U.S. college faculty members mirror the nation's demographics, then we must ensure that Black males have equal access to an affordable, quality college education resulting in degree completion.

Public affairs education is accredited by the Network of Schools of Public Policy, Affairs, and Administration (NASPAA), which represents 280 member institutions, of which 184 programs at 173 schools are accredited (Network of Schools of Public Policy, Affairs, and Administration [NASPAA], 2014b). As stated on the homepage of its website, 
NASPAA's mission is "to ensure excellence in education and training for public service, and promoting the ideal of public service" (Network of Schools of Public Policy, Affairs, and Administration [NASPAA], n.d.). Representative government and diversity are inherent in the ideal of public service, and NASPAA promotes diversity along the lines of faculty, students, and curricula to prepare students for the dynamic and changing environment of public service.

According to the 2013 NASPAA Diversity Report (Primo, 2013), diversity in public affairs programs has considerably increased since 2000. Using data from NASPAA-accredited programs from 2007 to 2013, Primo (2013) found that the percentage of minority students increased from 35\% in 2000 to $49 \%$ in 2013. Similarly, minority faculty at accredited programs increased from $9 \%$ in 2000 to $23 \%$ in 2013 (12\% African American, 7\% Asian, 4\% Hispanic, and less than $1 \%$ American Indian). The report also indicates greater representation of female students (59\% in 2013) and an increase in female faculty, from $12 \%$ in 2000 to $35 \%$ in 2013 . Despite overall significant gains, the aggregate data do not reveal which specific programs struggle with diversity.

In 2009, NASPAA-accredited programs approved new standards that emphasize mission-based accreditation with a focus on competencies and measurable outcomes. Programs seeking reaccreditation or new accreditation are reviewed by the Commission on Peer Review and Accreditation (COPRA) on the following NASPAA standards: (1) managing the program strategically; (2) matching governance with mission; (3) matching operations with mission: faculty performance; (4) matching operations with mission: serving students; (5) matching operations with mission: student learning; (6) matching resources with mission; and (7) matching communications with mission (NASPAA, 2014a).

Standards relevant to diversity include Standard 3.2 (faculty diversity), Standard 4.4 (student diversity), and Standard 5.1 (universal required competencies)—specifically the competency "to communicate and interact productively with a diverse and changing workforce and citizenry" (NASPAA, 2014a, p. 7). Standard 3.2 specifically states that "the program will promote diversity and a climate of inclusiveness through its recruitment and retention of faculty members" (NASPAA, 2014a, p. 5). Similarly, Standard 4.4 states that "the program will promote diversity and a climate of inclusiveness through its recruitment and admissions practices and student support services" (NASPAA, 2014a, p. 6).

The 2014 Self Study Instructions (NASPAA, 2014c) indicate that COPRA seeks a strategic diversity plan and evidence of programmatic efforts for each of these standards. Regarding faculty and student diversity, COPRA focuses on recruitment and retention efforts along with strategies to promote a climate of inclusiveness within the program. This provides a degree of flexibility for programs engaged in good-faith efforts that may experience unique obstacles to increasing diversity.

The universal required competencies in Standard 5.1 include the following abilities:

- to lead and manage in public governance;

- to participate in and contribute to the policy process;

- to analyze, synthesize, think critically, solve problems and make decisions;

- to articulate and apply a public service perspective;

- to communicate and interact productively with a diverse and changing workforce and citizenry. (NASPAA, 2014a, p. 7)

COPRA seeks operational definitions of each of the competencies and assessment of competencies in relation to the mission of the program.

The 2012-2013 NASPAA Annual Data Accreditation Report represents 180 accredited programs and 7 programs seeking accreditation 
for the first time (Camacho, 2014). To ease the transition to the 2009 NASPAA standards, schools were initially provided the option to seek reaccreditation under either the original standards or the 2009 standards. Among the 56 programs accredited under the current standards, 54\% were initially monitored under Standard 3.2: Faculty Diversity; 27\% were monitored under Standard 4.4: Student Diversity; and $79 \%$ were monitored under Standard 5.1: Universal Required Competencies, and specifically the assessment of the competencies (Camacho, 2014).

NASPAA and COPRA have worked diligently to assist member institutions seeking accreditation under the current standards. In addition to technical assistance, training, and publications on accreditation featured in the Journal of Public Affairs Education, NASPAA developed a WordPress resource hub on accreditation that can be found at http://accreditation.naspaa.org/. In addition, schools that have been recognized for diversity best practices are included in the NASPAA Diversity Report (Primo, 2013).

\section{POLICY RECOMMENDATIONS}

As one aspect of institutional racism, this article identifies procedures that lower college attainment for Black males and low-income students. Recognizing the barriers for Black students, on July 26, 2012, President Obama signed an executive order titled the "White House Initiative on Educational Excellence for African Americans." One of the goals is "increasing college access and success for African American students and providing support to help ensure that a greater percentage of African Americans complete college" (The White House, 2012). To ensure this goal is achieved, numerous policies need to be enacted. Specifically, Congress must prohibit predatory practices by for-profit institutions, which target vulnerable low-income populations. Currently, for-profit institutions receive $86 \%$ of their annual revenue ( $\$ 32$ billion) from the federal government, despite accounting for $50 \%$ of all student loan default rates in addition to low graduation rates (Mettler, 2014).
Second, Congress needs to critically examine and potentially regulate pricing practices by all degree-granting institutions to help students better understand and evaluate their college options. Third, degree-granting institutions across the country need to provide mentoring programs for Black male students before and during their college experience to increase degree completion.

Fourth, in light of the pervasiveness of the use of tracking and ability grouping in public education (Oakes \& Wells, 1998) and the consistent findings of the ineffectiveness of low-tracked classes (Heubert \& Hauser, 1999), it seems reasonable to dismantle these institutional practices and provide high-track curricula (AP courses) to all students regardless of their demographic characteristics, assessment scores, or prior academic achievement. Educational researchers who explore the relationship between race and academic performance offer empirical support for this recommendation as a strategy to close the achievement gap (Ogbu, 2003; Slavin, 1990).

A college education that is accessible, affordable, and attainable is a necessary condition of social equity.

\section{REFERENCES}

American Council on Higher Education (2015, June 24). Ruling clears the way for Education Department's gainful employment regulation. Retrieved from http://www.acenet.edu/news-room/Pages/RulingClears-the-Way-for-Education-DepartmentGainful-Employment-Regulation.aspx.

Association of Private Sector Colleges and Universities. (2012). Private sector colleges and universities: Essential to higher education, jobs, and the economy. Retrieved from http://www.apscu.org/knowledgecenter/facts/sector/upload/APSCULeave-Behind Sept12.pdf. 
Association of Private Sector Colleges and Universities. (2013). America's private sector colleges and universities: Generating real value for students and society. Retrieved from http://www.career.org/news-andmedia/press-releases/upload/APSCU-GeneratingReal-Value-Final.pdf.

Bailey, M. J., \& Dynarski, S. M. (2011). Inequality in postsecondary attainment. In G. Duncan \& R. Murnane (Eds.), Whither opportunity: Rising inequality, schools, and children's life chances (pp. 117132). New York, NY: Russell Sage Foundation.

Baum, S., Ma, J., \& Payea, K. (2013). Education pays, 2013: The benefits of higher education for individuals and society. Retrieved from the College Board website: http://trends.collegeboard.org/sites/ default/files/education-pays-2013-full-report022714.pdf.

Blumenstyk, G. (2015). American higher education in crisis? What everyone needs to know. New York, NY: Oxford University Press.

Bound, J., Hershbein, B., \& Long, B. T. (2009). Playing the admissions game: Student reactions to increasing college competition (NBER Working Paper No. 15272). Retrieved from the National Bureau of Economic Research website: http://www.nber.org/ papers/w15272.

Braddock, J. H., II. (1990). Tracking the middle grades: National patterns of grouping for instruction. Phi Delta Kappan, 71(6), 445-449.

Braddock, J. H., II, \& Dawkins, M. P. (1993). Ability grouping, aspirations, and attainment: Evidence from the national educational longitudinal study of 1988. Negro Education, 62(324), 326-329.

Camacho, C. (2014). 2012-2013 NASPAA annual data accreditation report. Retrieved from https:// naspaaaccreditation.files.wordpress.com/2014/04/ 2014-data-report.pdf.

Carnevale, A. P., \& Stroh, J. (2013). Separate and unequal: How higher education reinforces the intergenerational reproduction of White racial privilege. Washington, DC: Georgetown University, Center on Education and the Workforce.

Carnevale, A. P, Stroh, J., \& Gulish, A. (2015). College is just the beginning: Employers' role in the $\$ 1.1$ trillion post-secondary education and training system. Retrieved from the Georgetown University, Center on
Education and the Workforce, McCourt School of Public Policy website: https://cew.george town. edu/wp-content/uploads/2015/02/Trillion-DollarTraining-System-.pdf.

College Board. (2012). Trends in higher education, figure 1A. New York, NY: College Board. Retrieved from http://trends.collegeboard.org/sites/default/files/ college-pricing-2013-full-report.pdf.

College Board. (2013). Maximum Pell Grant award as percentage of tuition and fees and total charges over time. New York, NY: College Board.

Delisle, J. (2014). The graduate student debt review: The state of graduate borrowing [Policy paper]. Retrieved from the New America Foundation website: http:// www.newamerica.net/publications/policy/the_ graduate_student_debt_review.

DeNavas-Walt, C. \& Proctor, B.D. (2014, September 16). Income and poverty in the United States: 2013. U.S. Census Bureau, Report Number P60-249. Retrieved from http://www.census.gov/library/publications/ 2014/demo/p60-249.html.

Dixson, A. D., \& Rousseau, C. K. (2006). Introduction. In A. D. Dixson \& C. K. Rousseau (Eds.), Critical race theory in education: All God's children got a song (pp. 1-8). New York, NY: Routledge.

Frederickson, H. G. (2010). Social equity and public administration: Origins, developments and applications. Armonk, NY: M. E. Sharpe.

Ginder, S. A., \& Kelly-Reid, J. E. (2013). Postsecondary institutions and cost of attendance in 2012-13; degrees and other awards conferred, 2011-12; and 12-month enrollment, 2011-12 [Provisional data] (NCES 2013-289rev). Retrieved from http://nces.ed.gov/ pubs2013/2013289rev.pdf.

Goldrick-Rab, S., Kelchen, R., \& Houle, J. (2014, Sept. 2). The color of student debt: Implications of federal loan program reforms for black students and historically black colleges and universities. Wisconsin Hope Lab. Retrieved from https://news.education. wisc.edu/docs/WebDispenser/news-connections$\mathrm{pdf} /$ thecolorofstudentdebt-draft.pdf?sfvrsn $=4$.

Gooden, S. T. (2014). Race and social equality: A nervous area of government. New York, NY: M. E. Sharpe.

Heubert, J. P., \& Hauser, R. M. (1999). High stakes: Testing for tracking, promotion, and graduation. A 
report of the National Research Council. Washington, DC: National Academy Press.

Hoxby, C., \& Avery, C. (2013). The missing "oneoffs": The hidden supply of high-achieving, low income students. Washington, DC: The Brookings Institution.

Huelsman, M. (2015). The debt divide: The racial and class bias behind the "new normal" of student borrowing. Retrieved from the Demos website: http://www.demos.org/sites/default/files/ publications/The\%20Debt\%20Divide.pdf.

Isaacs, J. B., Sawhill, I., \& Haskins, R. (2008). Getting ahead or losing ground: Economic mobility in America. Washington, DC: Brookings Institution.

Krislov, S. (2013). Representative bureaucracy. Classics of the social sciences. New Orleans, LA: Quid Pro Books.

Ladson-Billings, G., \& Tate, W. (1995). Toward a Critical Race Theory of education. Teachers College Record, 97(1), 47-68.

Loveless, T. (1998, July). The tracking and ability grouping debate. Retrieved from http://edexcellence. net/publications/tracking.html.

Matsuda, M. (1991). Voices of America: Accent, antidiscrimination law, and a jurisprudence for the last reconstruction. Yale Law Journal, 100, 1329-1407.

Mettler, S. (2014). Degrees of inequality: How the politics of higher education sabotaged the American dream. New York, NY: Basic Books.

Mortenson, T.G. (2012). Family income and unequal educational opportunity, 1970-2011. Postsecondary Education Opportunity, 245. Retrieved from http:// www. postsecondary.org/topicslist.asp? page $=1 \&$ od $=$ \&search=Income\#.

Naff, K. C. (2001). To look like America: Dismantling barriers for women and minorities in government. Boulder, CO: Westview Press.

National Academy of Public Administration, Standing Panel on Social Equity in Governance. (n.d.). Definition of social equity. Retrieved from http:// www.napawash.org/fellows/standing-panels/socialequity-in-governance.html.

Naylor, L. A., Gerlowski, D. A., \& Seabrook, R. (in press). U.S. higher education: Transition and tur- bulence in the new model. Journal of Development \& Leadership.

Naylor, L. A., Wooldridge, B., \& Lyles, A. C. (2014). U.S. public administration programs: Increasing academic achievement by identifying and utilizing student learning styles. Teaching Public Administration Journal, 32(1), 68-79.

Network of Schools of Public Policy, Affairs, and Administration (NASPAA). (n.d.). [Web page]. Retrieved from http://www.naspaa.org/.

Network of Schools of Public Policy, Affairs, and Administration (NASPAA). (2014a). Accreditation standards for master's degree programs. Retrieved from https://naspaaaccreditation.files.wordpress.com/ 2015/02/naspaa-accreditation-standards.pdf.

Network of Schools of Public Policy, Affairs, and Administration (NASPAA). (2014b). 2014-2015 Roster of accredited programs. Retrieved from http:// accreditation.naspaa.org/resources/roster-ofaccredited-programs/.

Network of Schools of Public Policy, Affairs, and Administration (NASPAA). (2014c). Self study instructions. Retrieved from https://naspaaaccreditation. files.wordpress.com/2014/05/ssi-instructions2014-update-final.pdf.

Oaks, J., \& Wells, A. S. (1998). Detracking for high student achievement. Educational Leadership, 55(38), 41-48.

Ogbu, J. (2003). Black American students in an affluent suburb. Mahwah, NJ: Erlbaum.

Oldfield, K., Candler, G., \& Johnson, R. G. (2006). Social class, sexual orientation, and toward proactive social equity scholarship. American Review of Public Administration, 36(2), 156-172.

Organisation for Economic Co-operation and Development (OECD). (2013). Education at a glance: OECD indicators 2013. Retrieved from http://www.oecd.org/edu/eag2013\%20(eng)-FINAL\%2020\%20June\%202013.pdf.

Pebley, A. R., \& Sastry, N. (2004). Neighborhoods, poverty, and children's well-being. In K. M. Neckerman (Ed.), Social inequality (pp. 119-145). New York, NY: Russell Sage Foundation.

Pew Charitable Trusts. (2011). Does America promote mobility as well as other nations? Washington, DC: 
Author. Retrieved from http://www.russellsage. org/sites/all/files/does-america-promote-economicmobility.pdf.

Primo, N. (2013). NASPAA diversity report 2013. Retrieved from the NASPAA website: https:// naspaaaccreditation.files.wordpress.com/2015/02/ diversity-report-10-01-13.pdf.

Ripley,A.(2012,October 29). Highereducation: College is dead. Long live college! Time Magazine. Retrieved from http://nation.time.com/2012/10/18/collegeis-dead-long-live-college/.

Rivard, R. (2015, February 13). In Texas, questioning powers. Inside Higher Ed. Retrieved from https:// www.insidehighered.com/news/2015/02/13/ investigation-finds-ut-austin-president-influencedadmissions-decisions.

Slavin, R. (1990). Achievement effects of ability grouping in secondary schools: A best-evidence synthesis. Review of Educational Research, 60(3), 471-500.

Smith, J. I., Pender, M., \& Howell, J. S. (2013). The full extent of academic undermatch. Economics of Education Review, 32, 247-261.

Solorzano D. G., \& Yosso T. J. (2001). Critical race and LatCrit theory and method: Counter-storytelling Chicana and Chicano graduate school experiences. International Journal of Qualitative Studies in Education, 14(4), 471-495.

StateHigherEducationExecutiveOfficers. (2013). Higher education finance FY 2013. Retrieved from http:// www.sheeo.org/sites/default/files/publications/ SHEF_FY13_04292014.pdf.

Steele, C. M. (1997). A threat in the air: How stereotypes shape intellectual identity and performance. American Psychologist, 52(6), 613-629.

Stengel, R. (2012, October 18). Higher education: Reinventing college. Time Magazine. Retrieved from http://nation.time.com/2012/10/18/reinventingcollege/.

The solid progress of African Americans in degree attainments. (n.d.). The Journal of Blacks in Higher Education. Retrieved from http://www.jbhe.com/ features/52_degree-attainments.html.

Ture, K., \& Hamilton, C. (1992). Black power: The politics of liberation. New York, NY: Vintage. (Original work published 1967.)
U.S. Census Bureau. (n.d.). Historical time series tables. Table A-2. Reported Voting and Registration by Region, Educational Attainment, and Labor Force: November 1964 to 2012 [Data table]. Retrieved from http:// www.census.gov/hhes/www/socdemo/voting/publications/historical/index.html.

U.S. Census Bureau. (2012a). The Black Alone population in the United States. Table 1: Population by sex and age, for Black Alone and White Alone, not Hispanic: 2012 [Data table]. Retrieved from http://www.census.gov/population/race/data/pplba12.html.

U.S. Census Bureau. (2012b). The Black Alone population in the United States. Table 5. Educational attainment of the population 25 years and over by sex, for Black Alone and White Alone, not Hispanic: 2012 [Data table]. Retrieved from http://www.census. gov/population/race/data/ppl-ba12.html.

U.S. Census Bureau. (2012c). The Black Alone population in the United States. Table 21. Poverty status of the population by sex and age, for Black Alone and White Alone, not Hispanic: 2011 [Data table]. Retrieved from http://www.census.gov/population/ race/data/ppl-ba12.html.

U.S. Census Bureau. (2012d). The Black Alone population in the United States. Table 17. Earnings of full-time, year-round workers 15 years and over by sex, for Black Alone and White Alone, not Hispanic: 2011 [Data table]. Retrieved from http://www.census. gov/population/race/data/ppl-ba12.html.

U.S. Census Bureau. (2012e). The Black Alone population in the United States. Table 19. Total money income of households by type, for Black Alone and White Alone, not Hispanic households: 2011 [Data table]. Retrieved from http://www.census.gov/population/race/data/ppl-ba12.html.

U.S. Census Bureau. (2013). Educational attainment in the United States: 2013-detailed tables [Data tables]. Retrieved from http://www.census.gov/hhes/ socdemo/education/data/cps/2013/tables.html.

U.S. Department of Education, National Center for Education Statistics. (2013). Digest of Education Statistics, 2012. Retrieved from http://nces.ed.gov/ pubsearch/pubsinfo.asp?pubid=2014015.

U.S. Department of Education, National Center for Education Statistics. (2007). Digest of Education Statistics, 2006. Retrieved from http://nces.ed.gov/ pubsearch/pubsinfo.asp?pubid=2007017. 
U.S. Department of Education, National Center for Education Statistics. (2012a). Digest of Education Statistics, 2012. Table 236. Percentage of recent high school completers enrolled in 2-year and 4-year college, by income level, 1975 through 2011 [Data table]. Retrievedfromhttps://nces.ed.gov/programs/digest/ d12/tables/dt12_236.asp.

U.S. Department of Education, National Center for Education Statistics (2015). The condition of education 2015: Annual earnings of young adults. Retrieved from https://nces.ed.gov/programs/coe/ pdf/coe_cba.pdf.

U.S. Department of Labor, Bureau of Labor Statistics (2015). Earnings and unemployment rates by educational attainment. Retrieved http://www.bls.gov/ emp/ep_chart_001.htm.

U.S. Government Accountability Office. (2010). For-profit colleges: Undercover testing finds colleges encouraged fraud and engaged in deceptive and questionable marketing practices: Testimony before the Committee on Health, Education, Labor, and Pensions, U.S. Senate (GAO-10-948T). Retrieved from http://www.gao.gov/assets/130/125197.pdf.

Verba, S., Schlozman, K. L., \& Brady, H. (1995). Voice and equality: Civic volunteerism and American politics. Cambridge, MA: Harvard University Press.

Viadero, D. (1998, October 14). On the wrong track? Education Week. Retrieved from http://www.ed week.org/ew/articles/1998/09/23/07track.h18.html.

Washington v. Davis, 426 U.S. 229 (1976).

Welner, K. G., \& Oakes, J. (1996). (Li)ability grouping: The new susceptibility of school tracking systems to legal challenges. Harvard Education Review, 66(3), 451-471.

The White House, The Executive Office of the President. (2014). Increasing college opportunity for low-income students: Promising models and a call to action. Retrieved from http://www.whitehouse. gov/sites/default/files/docs/increasing_college_ opportunity_for_low-income_students_report.pdf.

The White House, Office of the Press Secretary. (2012). Executive Order-White House initiative on educational excellence for African Americans [Press release]. Retrieved from http://www.whitehouse. gov/the-press-office/2012/07/26/executive-orderwhite-house-initiative-educational-excellenceafrican-am.
Wyatt-Nichol, H., Brown, S. A., Haynes, W. E. (2011). Social class and socioeconomic status: Relevance and inclusion in MPA/MPP programs. Journal of Public Affairs Education, 17(2), 187-208.

\section{ABOUT THE AUTHORS}

Lorenda A. Naylor is an associate professor with the University of Baltimore in the School of Public and International Affairs. Naylor received her $\mathrm{PhD}$ in public administration from American University. She is a social equity researcher with specific emphasis on access for vulnerable populations. Her work has appeared in Journal of Public Affairs Education, Review of Public Personnel Administration, Public Integrity, Teaching Public Administration, Journal of Development and Leadership, and Journal of Health and Human Services.

Heather Wyatt-Nichol is as an MPA program director and associate professor in the College of Public Affairs at the University of Baltimore. She also serves as a commissioner for NASPAA's Commission on Peer Review and Accreditation. She has published book chapters and articles on a variety of topics in public administration and feminist journals. Her research interests include diversity management, ethics, family-friendly workplace policies, organizational justice, and social equity. Her work has appeared in Administrative Theory \& Praxis, International Journal of Organization Theory and Behavior, Journal of Health and Human Services Administration, Journal of Public Affairs Education, Journal of Public Management and Social Policy, Journal of the Association for Research on Mothering, Public Integrity, Public Personnel Management, and Virginia Police Chief.

Samuel L. Brown is a professor in the School of Public Administration and International Affairs in the College of Public Affairs at the University of Baltimore. His research is focused on developing theoretical frameworks and practical guidance to permit enhanced understandings 
of how American political institutions continue to foster the current barriers to achieving the democratic ideal of equality for all Americans. His more recent publication stream has focused in the area of social equity in public administration. His publications have appeared in both health and public administration journals. 